\title{
Professional ethics of recommendations: implications for COVID-19 vaccination of women who are pregnant or planning to become pregnant
}

\author{
Frank A. Chervenak ${ }^{\bowtie}$, Laurence B. McCullough, Amos Grünebaum \\ Department of Obstetrics and Gynecology Zucker School of Medicine at Hofstra/Northwell \\ Lenox Hill Hospital New York \\ 100 East 77th Str. New York, NY 10075, USA
}

\begin{abstract}
There has been changing guidance from national and international professional associations, national and international non-governmental organizations, and health officials in national governments for obstetrician-gynecologists about COVID-19 vaccination of pregnant women and women who are planning to become pregnant. in this paper, we provide an ethical framework that provides the needed guidance to decision making about recommending COVID-19 vaccination to these patients. the unique feature of this ethical framework is that it is based on professional ethics in obstetrics and gynecology. We begin with an account of three key components of professional ethics in obstetrics and gynecology and how they are pertinent to the ethics of making recommendations that should be understood in obstetric and gynecologic practice generally. We then identify the implications of this overview for the specific topic of the ethics of recommending COVID-19 vaccination.
\end{abstract}

Keywords: COVID-19; COVID-19 vaccination; ethical principle of beneficence; ethical principle of respect for autonomy; medically reasonable; professional ethics in obstetrics and gynecology

MeSH terms:

PREGNANCY COMPLICATIONS, INFECTIOUS - PREVENTION \& CONTROL

COVID-19 - COMPLICATIONS

COVID-19 - PREVENTION \& CONTROL

COVID-19 - VACCINES - THERAPEUTIC USE

VACCINATION - METHODS

VACCINATION - ETHICS

For citation: Chervenak F.A., McCullough L.B., Grünebaum A. Professional ethics of recommendations: implications for COVID-19 vaccination of women who are pregnant or planning to become pregnant. Sechenov Medical Journal. 2021; 12(2): 55-61. https://doi.org/10.47093/2218-7332.2021.12.2.55-61

CONTACT INFORMATION:

Frank A. Chervenak, MD, Department of Obstetrics and Gynecology Zucker School of Medicine at Hofstra/Northwell Lenox Hill Hospital New York

Address: 100 East $77^{\text {th }}$ Str. New York, NY 10075, USA

Tel.: + 12124344445

E-mail: fchervenak@northwell.edu

Conflict of interests. The authors declare that there is no conflict of interest.

Financial support. Supported by Departmental funds.

Received: 04.08.2021

Accepted: 09.08.2021

Date of publication: 29.09 .2021 


\title{
Профессиональная этика рекомендаций: значение вакцинации против COVID-19 беременных или планирующих беременность женщин
}

\author{
Ф.А. Червенак ${ }^{\bowtie}$, Л.Б. Маккалоу, А. Грюнебаум \\ Отделение акушерства и гинекологии Медицинской школы Цукер в Хофстра / Нортвелл \\ Больнииа Ленокс Хилл, Нью-Йорк \\ 100 Восток, 77-я ул., Нью-Йорк, 10075, США
}

\begin{abstract}
Аннотация
Внесены изменения в руководства национальных и международных профессиональных ассоциаций, национальных и международных неправительственных организаций, а также органов управления здравоохранения в национальных правительствах для акушеров-гинекологов в отношении вакцинации против COVID-19 беременных женщин и женщин, планирующих беременность. В этом документе представлены этические принципы, которые обеспечивают необходимое руководство для принятия решений о рекомендации вакцинации COVID-19 этой группе пациентов. Уникальная особенность этих этических принципов состоит в том, что они основаны на профессиональной этике в акушерстве и гинекологии. Обзор начинается с описания трех ключевых компонентов профрессиональной этики в акушерстве и гинекологии и того, как они соотносятся с этикой рекомендаций, которые следует принимать в акушерской и гинекологической практике в целом. Затем определяется значение этого обзора для конкретной темы рекомендации по вакцинации COVID-19.
\end{abstract}

Ключевые слова: COVID-19; вакцинация от COVID-19; этический принцип милосердия; этический принцип уважения автономии; медицинское обоснование; профессиональная этика в акушерстве и гинекологии

Рубрики MeSH:

БЕРЕМЕННОСТИ ОСЛОЖНЕНИЯ ИНФЕКЦИОННЫЕ - ПРОФИЛАКТИКА И КОНТРОЛЬ

COVID-19 - ОСЛОЖНЕНИЯ

COVID-19 - ПРОФИЛАКТИКА И КОНТРОЛЬ

COVID-19 ВАКЦИНЫ - ТЕРАПЕВТИЧЕСКОЕ ПРИМЕНЕНИЕ

ВАКЦИНАЦИЯ - МЕТОДЫ

ВАКЦИНАЦИЯ - ЭТИКА

Для цитирования: Червенак Ф.А., Маккалоу Л.Б., Грюнебаум А. Профессиональная этика рекомендаций: значение вакцинации против COVID-19 беременных или планирующих беременность женщин. Сеченовский вестник. 2021; 12(2): 55-61. https://doi.org/10.47093/2218-7332.2021.12.2.55-61

КОНТАКТНАЯ ИНФОРМАЦИЯ:

Фрэнк А. Червенак, MD, Отделение акушерства и гинекологии, Медицинская школа Цукер в Хофстра / Нортвелл, Больница Ленокс Хилл, Нью-Йорк

Адрес: 100 Восток, 77-я ул., Нью-Йорк, 10075, США

Тел.: + 12124344445

E-mail: fchervenak@northwell.edu

Конфликт интересов. Авторы заявляют об отсутствии конфликта интересов.

Финансирование. Исследование поддерживается ведомственными фондами.

Поступила: 04.08 .2021

Принята: 09.08.2021

Дата печати: 29.09.2021 
HIGHLIGHTS

Professional ethics in obstetrics and gynecology should guide obstetrician-gynecologists in counselling pregnant patients about COVID-19 vaccination.

Obstetrician-gynecologists should recommend COVID-19 vaccination to their pregnant patients and patients who are planning to become pregnant.

Making recommendations about clinical management to pregnant patients is routine in obstetric practice. Obstetricians make a range of recommendations to patients, about, for example, coming in for prenatal visits, diet and exercise, and refraining from the use of tobacco products and consuming alcohol beverages. Such recommendations promote both maternal and fetal health. Obstetricians also make recommendations to protect maternal health, e.g., cesarean delivery to manage pre-eclampsia, and to protect fetal and neonatal health, cesarean delivery for severe fetal distress. Obstetricians recommend the flu vaccine each year.

In this context, it should be of considerable concern to obstetrician-gynecologists that currently there is conflicting guidance from national and international professional associations, national and international non-governmental organizations, and health officials in national governments about COVID-19 vaccination of pregnant women and women who are planning to become pregnant. the purpose of this paper is to provide an ethical framework that provides clear guidance to decision making about recommending COVID-19 vaccination to these patients. This ethical framework is based on professional ethics in obstetrics and gynecology [1]. We therefore start with an overview of three key components of professional ethics in obstetrics and gynecology and how they are pertinent to the ethics of making recommendations that should be understood in obstetric and gynecologic practice generally. We then identify the implications of this overview for the specific topic of the ethics of recommending COVID-19 vaccination.

\section{THREE COMPONENTS OF PROFESSIONAL ETHICS IN OBSTETRICS AND GYNECOLOGY Ethical principles}

The three components of the proposed ethical framework are two ethical principles - beneficence and respect for autonomy - and the clinical ethical concept of medical reasonableness. Ethical principles and clinical ethical concepts are designed to provide clear, practical guidance to clinical judgment and clinical management [1].

\section{The ethical principle of beneficence}

The ethical principle of beneficence is the older of the two ethical principles. One of the first
КЛЮЧЕВЫЕ ПОЛОЖЕНИЯ

Профессиональная этика в акушерстве и гинекологии должна служить ориентиром для акушеров-гинекологов при консультировании беременных по поводу вакцинации против COVID-19.

Акушеры-гинекологи должны рекомендовать вакцинацию от COVID-19 беременным пациенткам и пациенткам, которые планируют беременность.

occurrences of the word "beneficence" in the global history of medical ethics occurs in the first book entitled, "Medical Ethics", by the English physician-ethicist, Thomas Percival (1740-1804), and published in 1803. Percival invokes the principle of beneficence when he sets out an ethical framework for the responsible use of "drugs and wines" - fortified wines then being thought to aid in the treatment of digestive disorders and to calm nerves - in the formulary of the Manchester Royal Infirmary in England. Their use should be guided by "beneficence", by which Percival meant an evidencebased evaluation of their efficacy $[2,3]$.

Percival's account contains a compressed version of the ethical principle, which is not surprising given that he is perhaps the first explicit invocation of the principle. the ethical principle of beneficence was fully formulated in the last third of the previous century. It creates the ethical obligation of the physician to identify and provide clinical management that in evidence-based clinical management is predicted to result in net clinical benefit for the patient, a greater balance of clinical goods over clinical harms. the clinical goods include the management as well as the prevention of disease and disability and the prevention of death (though not at all costs). the clinical harms include especially pain, distress, and suffering, as well as preventable death. With Percival, we emphasize that the evidence base for beneficence-based clinical judgment does not include the physician's idiosyncratic views or unanalyzed "personal experience". the latter is usually distorted by unrecognized biases, which evidence-based reasoning is designed to critically appraise and mitigate [1].

The reliability of beneficence-based clinical judgment is a function of its evidence base. the stronger the evidence base, the more reliable are the clinical judgments based on it. Conversely, the weaker the evidence base, the less reliable are the clinical judgments based on it.

\footnotetext{
The beneficence-based concept of medical reasonableness

When a form of clinical judgment is supported in beneficence-based clinical judgment it is known in professional ethics in medicine as "medically reasonable". Forms of clinical management that are not supported in beneficence-based clinical judgment are not medically reasonable and should therefore not be included in the clinical management of the patient's
} 
condition (pregnancy is a condition, not a disease or disability), disease, or disability [1].

\section{The ethical principle of respect for autonomy}

The ethical principle of respect for autonomy also has its origins in eighteenth-century British medical ethics, in the work of Percival's predecessor, the Scottish physician-ethicist John Gregory (1724-1773). in his lectures on medical ethics to his students, published in $1772[4,5]$ Gregory supports the ethical obligation of physicians to be honest with gravely ill patients about the clinical gravity and implications of end-stage disease and injury. He also states that patients have the "right to speak" when their own health or life is at stake. Physicians have the ethical obligation to listen and to evaluate the patient's views and preferences. When these are what we would now call medically reasonable, the physician should endorse them. When the patient's views and preferences are not medically reasonable the physician should withhold endorsement - and be prepared for the adverse outcomes that might follow and provide clinical management of them without comment or, especially, complaint.

Like the ethical principle of beneficence, the ethical principle of respect for autonomy was fully formulated in the last third of the twentieth century. This principle integrates the beneficence-based concept of medical reasonableness with respect for the patient's right "to speak" or, as we would now say, the patient's right to self-determination. the ethical principle of respect for autonomy creates the ethical obligation of the physician to empower each patient to make informed and voluntary decisions about the clinical management of her condition, disease, or diagnosis. the physician empowers the patient to make informed decisions by providing her with information on her condition or diagnosis and about the medically reasonable alternatives for the clinical management of her condition or diagnosis, as well as the clinical benefits and risks of each such alternative. the physician empowers the patient to make voluntary decisions by making a reasonable effort to ensure that the patient's decision-making process is free of both internal controlling influences and external controlling influences. Psychosocial support should be provided, as needed, with the goal of achieving voluntary decision making [1].

\section{Offering and recommending clinical management}

Sometimes more than one medically reasonable alternative is supported in beneficence-based clinical judgment. For example, trial of labor after a previous cesarean delivery by a low transverse incision is supported in beneficence-based clinical judgment as medically reasonable and so is planned cesarean delivery [6]. When there are two or more medically reasonable alternatives, the ethical principle of respect for autonomy creates the ethical obligation to offer both and to support the patient to understand and evaluate each alternative based on her values and beliefs. Inasmuch as the physician is not able to determine which alternative better supports the patient's values and beliefs, the physician should not make a recommendation. Instead, shared decision making - in the sense of offering but not recommending the medically reasonable alternatives in the context of the patient's values and beliefs - should guide the physician's role in the patient's decision-making process [1].

Sometimes there is only one medically reasonable form of clinical management, for example, cesarean delivery to manage well-documented, intrapartum complete placenta previa. This form of clinical management dramatically reduces the risk of maternal mortality and essentially eliminates the risk of stillbirth and neonatal mortality. These clinical realities mean that there is no support in beneficence-based clinical judgment for vaginal delivery. Cesarean delivery should therefore be unhesitatingly recommended, and if necessary, strongly support the patient's decision making. Shared decision making, in the meaning described above, is not the appropriate model for decision making because it conveys the false impression that not accepting the recommendation of the only medically reasonable alternative, i.e., not being vaccinated against COVOD-19, is acceptable in professional ethics in obstetrics and gynecology [1].

Some take the view that making recommendations is not compatible with the ethical principle of respect for autonomy and do so in the name of championing the rights of patients, especially women who are patients [7]. This is, to say the least, ironic, since this view, to be plausible, must assume that female and pregnant patients are systematically at risk of being controlled by their physicians. This view infantilizes female and pregnant patients. Worse still, it combines the influencing of a patient's decision making (which recommendations are undoubtedly meant to do) with asserting a controlling influence. This is a conceptual error and conceptual errors are not permitted in ethical reasoning, just as they are not permitted in scientific and clinical reasoning. This view is also inconsistent with evidence-based reasoning: patients report that their physicians' recommendations are the most important consideration in their decision making about clinical management [8]. the claim that making recommendations is not compatible with the ethical principle of respect for autonomy therefore fails and should be discarded.

\section{Offering vs. recommending COVID-19 vaccination}

There is a crucial difference between shared decision making and making recommendations. Shared decision making starts with the patient's values and beliefs about COVID-19 vaccination, which becomes the controlling factor of the decision-making process. This means that 
the physician has the autonomy-based ethical obligation not to challenge but always to support the decision of the patient, including refusing the COVID-19 vaccination. Making recommendations about COVID-19 vaccination starts with the clinical reality that there is only one medically reasonable alternative, which becomes the controlling factor of the physician's clinical judgment and therefore in the decision-making process. This means that the physician has the ethical obligation to respectfully challenge the decision of a pregnant patient or patient planning to become pregnant to refuse COVID-19 vaccination.

The form that this respectful challenge should take is guided by the ethical principle of respect for autonomy: to empower the patient to reconsider her refusal in the context of the preventable clinical risks that implementing her refusal creates. in the United States, when patients refuse recommended clinical management, the physician has the legal obligation of informed refusal. the physician should inform the patient about the risks that refusal creates and document this disclosure in the patient's record. Doing so reduces the physician's professional liability should those risks occur [1]. There is an ethical dimension to informed refusal that applies in all settings globally: in a respectful manner the physician should point out refusing the COVID-19 vaccination means that the patient will have to rely on other measures such as masking and maintaining the prescribed distance from others, and these measures are not as effective as full immunization. the goal is to empower the patient to understand that these risks exist and that they could happen to her. She should be asked what she would think if those risks did indeed happen to her. in virtually all cases, the patient will express concern. She should be asked why to elicit her values and beliefs about protecting her life and health and that of her fetus. the physician can then point out the common ground that exists between the physician and the patient: the value of protecting both the life and health of the patient. the physician can then explain that this common ground motivates the recommendation of COVID-19 vaccination. the physician should repeat the recommendation as the only way to implement her values and beliefs.

This process of eliciting the patient's values about protecting her life and health, making common ground explicit, and re-iterating the recommendation as the way to implement the patient's values and beliefs is known as respectful persuasion [1], an important but underappreciated clinical tool for implementing the ethical principle of respect for patient autonomy. the justification for using this tool is evidence that patients consider the physician's recommendation as very important in their decision making [8]. Making recommendations coupled with respectful persuasion should both be understood as autonomy-enhancing.

\section{Recommending COVID-19 vaccination to pregnant women and women planning to become pregnant}

The ethical principle of beneficence should guide the physician's assessment of the benefits and risks of COVID-19 vaccination for pregnant women and women planning to become pregnant [9]. This assessment begins with the risk of not being vaccinated. COVID-19 is a more serious disease for infected pregnant patients than it is for non-pregnant patients. Pregnant women and recently pregnant women are at an increased risk for severe illness and other pregnancy complications from COVID-19 when compared to non-pregnant women [10-14]. Severe illness means that a person with COVID-19 may more likely need to be hospitalized, be admitted to an intensive care unit, or be on a ventilator.

In addition, pregnant women with COVID-19 are also at increased risk for preterm birth (delivering the baby earlier than 37 weeks) and might be at increased risk for other poor pregnancy outcomes.

Having certain underlying medical conditions, and other factors, including age, can further increase a pregnant or recently pregnant (for at least 42 days following the end of pregnancy) woman's risk for developing severe COVID-19 illness.

After pregnancy, changes that occur in the body during pregnancy that increase the risk for severe illness from respiratory viral infections like COVID-19 can continue. For example, increased risk for developing blood clots during pregnancy can continue after pregnancy and increase the risk for severe illness, as in recently pregnant people with H1N1 influenza.

This risk can be reduced by wearing an appropriate mask and maintaining social distance, but these are not as effective as vaccination. This is especially the case in a country with a low vaccination rate, currently reported to be $25.84 \%$ in Russia ${ }^{1}$. the recently completed placebo-controlled randomized trial of the GAM-COVID-Vac showed $91.6 \%$ efficacy with a good safety profile [15-17]. These results are like those reported for the mRNA vaccines [9]. Fully vaccinated patients may continue to use masks and maintain social distance, but the need to do so will diminish. the resulting increase in personal freedom is an important psychosocial benefit that should not be discounted. the risks of the vaccine are rare and, in most cases, clinically manageable. the public health implications of a vaccine with $91.6 \%$ efficacy are significant. This significance increases in countries like Russia with low current vaccination rates.

\section{CONCLUSION}

Beneficence-based clinical judgment is clear on two points. First, not being vaccinated against COVID-19 is not a medically reasonable alternative for pregnant

\footnotetext{
Our World in Data. Coronavirus (COVID-19) Vaccinations. https://ourworldindata.org/covid-vaccinations?country=RUS Accessed Aug $4^{\text {th }}$, 2021.
} 
women or for women planning to become pregnant. Second, the vaccine currently available in Russia is highly effective with a good safety profile. This conclusion can be made with confidence even in the absence of a randomized clinical trial with pregnant women and women planning to become pregnant in an intervention arm. This beneficence-based clinical judgment is the same that the authors and their colleagues at Northwell Health reached concerning vaccines with emergency approval from the U.S. Food and Drug Administration, even in the absence of such a randomized clinical trial [9]. There we argued that this beneficence-based clinical judgment

\section{AUTHOR CONTRIBUTIONS}

All authors participated in the research for this paper and its design. All authors participated in preparing successive drafts of the paper and therefore have read and approved the submitted text.

\section{REFERENCES / ЛИTEРATУPA}

1. McCullough L.B., Coverdale J.H., Chervenak F.A. Professional ethics in obstetrics and gynecology 1st Edition. New York and Cambridge: Cambridge University Press, 2020. 198 p. ISBN: 978-1316631492

2. Percival T. Medical ethics; or, a code of institutes and precepts, adapted to the professional conduct of physicians and surgeons. London: Johnson \& Bickerstaff, 1803.

3. McCullough L.B. Thomas Percival's medical ethics and the invention of medical professionalism: with three essential Percival texts, two concordances, and a chronology. 1st ed. New York: Springer, 2022. ISBN 978-3-030-86035-6

4. Gregory J. Lectures on the Duties and Qualifications of a Physician. London: W. Strahan and T. Cadell, 1772. in McCullough LB ed. John Gregory's writings on medical ethics and philosophy of medicine. Dordrecht: Springer, 1998: 161-245. ISBN 978-0585-32315-2

5. McCullough L.B. John Gregory and the invention of professional medical ethics and the profession of medicine. Dordrecht: Springer, 1998; 306 p. ISBN 978-0-585-27162-0

6. Chervenak F.A., McCullough L.B. An ethical framework for the informed consent process for trial of labor after cesarean delivery. Clin Perinatol. 2011 Jun; 38(2): 227-231. https://doi. org/10.1016/j.clp.2011.03.002. PMID: 21645791.

7. Ecker J., Minkoff $H$. Home birth: what are physicians' ethical obligations when patient choices may carry increased risk? Obstet Gynecol. 2011 May;117(5): 1179-1182. https://doi.org/10.1097/ AOG.0b013e3182167413. PMID: 21508760.

8. Kilich E., Dada S., Francis M.R., et al. Factors that influence vaccination decision-making among pregnant women: a systematic review and meta-analysis. PLoS One. 2020 Jul 9; 15(7): e0234827. https://doi.org/10.1371/journal.pone.0234827. PMID: 32645112.

9. Chervenak F.A., McCullough L.B., Bornstein E., et al. Professionally responsible coronavirus disease 2019 vaccination counseling of obstetrical and gynecologic patients. Am J Obstet Gynecol. 2021 May; 224(5): 470-478. https://doi.org/10.1016/j. ajog.2021.01.027. Epub 2021 Feb 1. PMID: 33539825.

10. Zambrano L.D., Ellington S., Strid P., et al. Update: Characteristics of symptomatic women of reproductive age with laboratoryconfirmed SARS-CoV-2 infection by pregnancy status - United States, January 22-October 3, 2020. MMWR Morb Mortal Wkly supports COVID-19 vaccination as the only medically reasonable alternative for preventing COVID-19 in pregnant patients and in patients planning to become pregnant. There we showed that in ethical reasoning this beneficence-based clinical judgment supports recommending COVID-19 vaccination to these patients is a matter of professional responsibility. Here we draw the same conclusion from the same beneficence-based clinical judgment. Obstetrician-gynecologists and other physicians in Russia, and in every other country, should recommend COVID-19 vaccination to their patients who are pregnant and to their patients who are planning to become pregnant.

\section{ВКЛАД АВТОРОВ}

Все авторы участвовали в организации и проведении исследования для написания этой статьи. Все авторы участвовали в последовательной подготовке текста статьи, прочитали и одобрили представленный текст.

Rep. 2020 Nov 6; 69(44): 1641-1647. https://doi.org/10.15585/ mmwr.mm6944e3. PMID: 33151921.

11. Allotey J., Stallings E., Bonet M., et al. Clinical manifestations, risk factors, and maternal and perinatal outcomes of coronavirus disease 2019 in pregnancy: living systematic review and metaanalysis. BMJ. 2020 Sep 1; 370:m3320. https://doi.org/10.1136/ bmj.m3320. PMID: 32873575.

12. Galang R.R., Newton S.M., Woodworth K.R., et al. Risk factors for illness severity among pregnant women with confirmed severe acute respiratory syndrome coronavirus 2 infection-surveillance for emerging threats to mothers and babies network, 22 State, Local, and Territorial Health Departments, 29 March 2020-5 March 2021. Clin Infect Dis. 2021 Jul 15;73(Suppl 1): S17-S23. https://doi.org/10.1093/cid/ciab432. PMID: 34021332.

13. Ko J.Y., DeSisto C.L., Simeone R.M., et al. Adverse pregnancy outcomes, maternal complications, and severe illness among us delivery hospitalizations with and without a coronavirus disease 2019 (COVID-19) diagnosis. Clin Infect Dis. 2021 Jul 15; 73(Suppl 1): S24-S31. https://doi.org/10.1093/cid/ciab344. PMID: 33977298 .

14. Woodworth K.R., Olsen E.O., Neelam V., et al. Birth and infant outcomes following laboratory-confirmed SARS-CoV-2 infection in pregnancy - SET-NET, 16 Jurisdictions, March 29 - October 14, 2020. MMWR Morb Mortal Wkly Rep. 2020 Nov 6; 69(44): 1635-1640. https://doi.org/10.15585/mmwr.mm6944e2. PMID 33151917 .

15. Logunov D.Y., Dolzhikova I.V., Shcheblyakov D.V., et al. Safety and efficacy of an rAd26 and rAd5 vector-based heterologous prime-boost COVID-19 vaccine: an interim analysis of a randomised controlled phase 3 trial in Russia. Lancet. 2021 Feb 20; 397(10275): 671-681. https://doi.org/10.1016/S01406736(21)00234-8. Epub 2021 Feb 2. Erratum in: Lancet. 2021 Feb 20; 397(10275): 670. PMID: 33545094.

16. Jones I., Roy P. Sputnik V COVID-19 vaccine candidate appears safe and effective. Lancet. 2021 Feb 20; 397(10275): 642-643. https://doi.org/10.1016/S0140-6736(21)00191-4. Epub 2021 Feb 2. PMID: 33545098.

17. Baraniuk C. Covid-19: What do we know about Sputnik V and other Russian vaccines? BMJ 2021 Mar 19; 372: n743. https://doi. org/10.1136/bmj.n743. PMID: 33741559. 


\section{INFORMATION ABOUT THE AUTHORS / ИНФОРМАЦИЯ ОБ АВТОРАХ}

Frank A. Chervenak ${ }^{\bowtie}, \mathrm{MD}$, Department of Obstetrics and Gynaecology Zucker School of Medicine at Hofstra / Northwell Lenox Hill Hospital, New York.

ORCID: https://orcid.org/0000-0002-4600-0853

Laurence B. McCullough, PhD, Department of Obstetrics and Gynaecology Zucker School of Medicine at Hofstra / Northwell Lenox Hill Hospital, New York.

ORCID: https://orcid.org/0000-0002-9505-0611

Amos Grünebaum, MD, Department of Obstetrics and Gynaecology Zucker School of Medicine at Hofstra / Northwell Lenox Hill Hospital, New York.

ORCID: https://orcid.org/0000-0002-0308-0232
Червенак Фрэнк A. ${ }^{\bowtie}, \mathrm{MD}$, Отделение акушерства и гинекологии Медицинской школы Цукер Хофстра / Нортвелл, больница Ленокс Хилл, Нью-Йорк. ORCID: https://orcid.org/0000-0002-4600-0853

Маккалоу Лоуренс Б., $\mathrm{PhD}$, Отделение акушерства и гинекологии Медицинской школы Цукер Хофстра / Нортвелл, больница Ленокс Хилл, Нью-Йорк. ORCID: https://orcid.org/0000-0002-9505-0611

Грюнебаум Амос, MD, Отделение акушерства и гинекологии Медицинской школы Цукер Хофстра / Нортвелл, больница Ленокс Хилл, Нью-Йорк.

ORCID: https://orcid.org/0000-0002-0308-0232

Автор, ответственный за переписку / Corresponding author 